Summer 2013

\title{
Scalia \& Garner's Reading Law: A Civil Law for the Age of Statutes?
}

James Maxeiner

University of Baltimore School of Law, jmaxeiner@ubalt.edu

Follow this and additional works at: http://scholarworks.law.ubalt.edu/all_fac

Part of the Civil Law Commons, Judges Commons, and the Supreme Court of the United States Commons

\section{Recommended Citation}

Scalia \& Garner's Reading Law: A Civil Law for the Age of Statutes?, 6 J. Civ. L. Stud. 1 (2013)

This Article is brought to you for free and open access by the Faculty Scholarship at ScholarWorks@University of Baltimore School of Law. It has been accepted for inclusion in All Faculty Scholarship by an authorized administrator of ScholarWorks@University of Baltimore School of Law. For more information, please contact snolan@ubalt.edu. 


\title{
SCALIA \& GARNER's READING LAW: A Civil LaW for the Age of Statutes?
}

\author{
James R. Maxeiner*
}

I. Abstract.......................................................................... 1

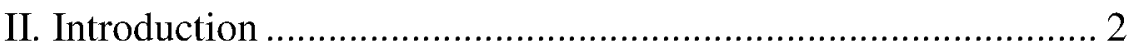

III. Scalia \& Garner: Common Law-Tradition is the Problem ....... 6

IV. Scalia \& Garner: [Pure] Textualism is the Solution .............. 12

V. Is Textualism a Civil Law for the Age of Statutes? ............... 16

A. Textualism is Civil .......................................................... 17

B. Pure Textualism is Uncivil .......................................... 20

VI. In Modern Civil Law Textualism and Non-Textualism Coexist

A. Law in Time Requires that Textualism and Non-Textualism Must Coexist ............................................................... 23

B. Reading Law is Doctrinal Rather than Authoritative.......... 25

C. Writing Law in the Age of Statutes................................. 26

D. Applying Law in the Age of Statutes............................. 30

VI. Common Law Procedure is A Problem ................................ 31

VII. Conclusion .................................................................. 34

\section{ABSTRACT}

In Reading Law: The Interpretation of Legal Texts, U.S. Supreme Court Justice Antonin Scalia and American legal lexicographer Bryan A. Garner challenge Americans to start over in dealing with statutes in the Age of Statutes. They propose

* (C) 2013 James R. Maxeiner, J.D., LL.M., Ph.D. in Law (Dr. jur., under Prof. Dr. Wolfgang Fikentscher, Munich), Associate Professor of Law, Associate Director, Center for International and Comparative Law, University of Baltimore School of Law. I would like to thank Philip K. Howard and the Common Good Institute for their support and the University of Baltimore for providing a summer research stipend. 
"textualism," i.e., "that the words of a governing text are of paramount concern, and what they convey in their context is what the text means." Textualism is meant to remedy the American lack of "a generally agreed-on approach to the interpretation of legal texts." That deficiency makes American law unpredictable, unequal, undemocratic and political. In the book's Foreword, Chief Judge Frank Easterbrook calls the book "a great event in American legal culture." It is a remarkable book because it challenges common law traditions. This review essay shows how Scalia and Garner challenge common law and summarizes the content of their challenge.

This article contrasts the methods of Reading Law with the methods of the Continental civil law. It shows that textualism is consistent with modern civil law methods. It also shows, however, that pure textualism, which largely restricts interpretation to grammatical and historical interpretation and excludes non-textual interpretation such as equitable, pragmatic and purposive approaches, is not consistent with modern civil law methods. In modern civil law, textualism and non-textualism coexist. They must, if law is to honor legal certainty, justice and policy.

\section{INTRODUCTION}

In Reading Law: The Interpretation of Legal Texts, ${ }^{1}$ U.S. Supreme Court Justice Antonin Scalia and American legal lexicographer Bryan A. Garner challenge Americans to start over in dealing with statutes in the Age of Statutes. ${ }^{2}$ They propose "textualism," i.e., "that the words of a governing text are of paramount concern, and what they convey in their context is what

1. ANTONIN SCALIA \& BRyAN A. GARNER, READING LAW: THE INTERPRETATION OF LEGAL TEXTS (West 2012). [Hereinafter SCALIA \& GARNER, READING LAW.]

2. See Guido Calabresi, A COMmon LAw for the Age of Statutes (Harvard Univ. Press 1982); JAMES WiLlard HuRst, DEALING WITH STATUTES (Columbia Univ. Press 1982). 
the text means." 3 Textualism is meant to remedy America's lack of "a generally agreed-on approach to the interpretation of legal texts." 4 That deficiency makes American law unpredictable, unequal, undemocratic and political.

Reading Law is a how-to handbook for judges who want to apply textualism in their daily work. It is not an academic monograph that argues the merits of textualism and the demerits of non-textualism. Scalia and Garner advise, "Our approach is unapologetically normative, prescribing what, in our view, courts ought to do with operative language." Reading Law consists of a six-page foreword, a four-page preface, a forty-six page introduction, seventy short chapters of two-to-ten pages each, a four-page afterword, a ten-page appendix on the use of dictionaries, a seventeen-page glossary of legal interpretation and an sixty-four page bibliography of cases, books and articles. The seventy short chapters address fifty-seven "Sound Principles of Interpretation" (broken down into five "fundamental principles" and fifty-two canons classified in various types) and a section of "Thirteen Falsities Exposed."

In the book's Foreword, Chief Judge Frank Easterbrook calls the book "a great event in American legal culture. . . [N] $[\mathrm{N}$ since Justice Story has a sitting Justice of the Supreme Court written about interpretation as comprehensively . ..."6 In the 1830s Story described an approach to interpretation of legal texts much like that which Scalia and Garner and propose today. ${ }^{7}$ Story went further, however, and addressed codification of law. ${ }^{8}$

3. SCALIA \& GARNER, READING LAW, supra note 1 , at 441.

4. $\quad I d$. at Xxvii.

5. Id. at 9 .

6. Frank H. Easterbrook, Foreword to SCALIA \& GARNER, READING LAW, supra note 1 , at xxvi.

7. Where Scalia and Garner provide fifty-seven "Sound Principles of Interpretation," Story offered his own non-exhaustive list of twenty-one "fundamental maxims" for the interpretation of statutes. Appendix III (Law, Legislation, Codes), in 7 ENCYClOPADIA AMERICANA. A POPULAR DiCTIONARY of ARTS, SCIENCE, LITERATURE, HiSTORY, POLITICS AND BIOGRAPHY, BROUGHT DOWN TO THE PRESENT TIME; INCLUDING A COPIOUS COLLECTION OF ORIGINAL 
The affinity of Scalia and Garner's work to Story's is not coincidental. The problem that Scalia and Garner address today grows out of the failure of American law to adequately resolve the codification controversy of more than a century ago. The controversy arose out of the need of the nation for rational law to support the ever increasing volume of commerce. It pitted proponents of codes, on the one hand, who wanted systematic, rational statements of rules along the lines of the French codes of

ARTICLES IN AMERICAN BIOGRAPHY; ON THE BASIS OF THE SEVENTH EDITION OF THE GERMAN CONVERSATIONS-LEXICON 576, 585 (Francis Lieber ed., Carey and Lea 1831) [hereinafter ENCYCLOPADIA AMERICANA]. His work on the principles of constitutional interpretation is better known. See 1 JOSEPH STORY, COMMENTARIES ON THE CONSTITUTION OF THE UNITED STATES 344-442 (Hilliard, Grey and Co. 1833); JOSEPH STORY, COMMENTARIES ON THE COnstitution of THE United StATES 123-162 (abridged ed., Hilliard, Grey and Co. 1833).

It is remarkable that Scalia and Garner did not note this work in their otherwise exhaustive bibliography and that Easterbrook does not seem to be aware of it. Story's authorship was known in his lifetime, and the article has been reprinted three times in modern works separately from the ENCYCLOPEDIA AMERICANA. See JAMES MCClELlan, JOSEPH STORY AND THE AMERICAN CONSTITUTION 350-372 (1971; 2d ed. with an Introduction by Stephen Presser, 1990); JOSEPH STORY AND THE ENCYCLOPEDIA AMERICANA. WITH AN ORIGINAL INTRODUCTION BY MORRIS L. COHEN (Valerie L. Horowitz ed., Lawbook Exchange, Ltd. 2006). The later volume reprints the seventeen other articles by Story in the ENCYCLOPEDIA AMERICANA.

8. As Chairman of the Codification Commission in Massachusetts, compiler of federal laws, author of the leading treatise on constitutional law, professor at Harvard Law School, and Supreme Court justice, he was a major participant in the codification controversy that occupied much of American legal discourse in the nineteenth century. See JOSEPH STORY ET AL., REPORT OF THE COMMISSIONERS APPOINTED TO CONSIDER AND REPORT UPON THE PRACTICABILITY AND EXPEDIENCY OF REDUCING TO A WRITTEN AND SYSTEMATIC CODE THE COMMON LAW OF MASSACHUSETTS, OR ANY PART THEREOF (Dutton \& Wentworth 1837), available at http:/Www archive.org/details/Reportofcommissi 1837 mass (last visited 4/19/13); THE PUBLIC AND GENERAL STATUTES PASSED BY THE CONGRESS OF THE UNITED STATES OF AMERICA FROM 1789 TO 1827 INCLUSIVE. PUBLISHED UNDER THE INSPECTION OF JOSEPH STORY (Wells \& Lilly 1827), available at http://catalog.hathitrust.org/Record/001625604 (last visited 4/19/13); JOSEPH STORY, A DISCOURSE PRONOUNCED UPON THE INAUGURATION OF THE AUTHOR, AS DANE PROFESSOR OF LAW IN HARVARD UNIVERSITY (Willard, Gray, Little \& Wilkins 1829), available at http:/www.archive.org/ details/discoursepronoun08stor (last visited 4/19/13); CHARLES SUMNER, THE SChOlar, THE Jurist, THE ARTist, the Philanthropist (William D. Ticknor \& Co. 1846), available at http://catalog.hathitrust.org/Record/011212036 (last visited 4/19/13). 
1804, applied justly and predictably, against proponents of common law rules and common law methods.

The conflict concluded at the end of the $19^{\text {th }}$ centuryunresolved - with the deaths of proponents and opponents alike. Inertia, and not conscious decision, determined America's present legal methods. Throughout the century, while proponents and opponents debated the issues, legislatures churned out statutes and judges produced precedents. The bar remained unmoved in opposition to codes and unshaken in devotion to lawyer-controlled common law methods. The newly-established law schools chose to teach precedents and case law methods rather than to develop codes and statutory methods. By century's end, proponents of codes had passed away, but legislative mills ground on and judges kept deciding as they always had. Since 1900, the United States has had uncodified statutory law combined with common law methods: a remarkable and costly mismatch. ${ }^{9}$

Scalia and Garner try to end this mismatch; they try to resurrect interpretive methods last addressed, they say, a century ago. ${ }^{10}$ They identify and try to kill the cause of American stagnation: common law methods. Having cleared out the clutter of common law methods, they propose textualism to move the United States forward.

Reading Law presents one possible solution to the proliferation of statutes. What makes it potentially a great event in American legal culture is its attack on common law. Not since David Dudley Field, Jr. has anyone of such stature in the American legal community sought to push aside common law methods to deal with statutes. Part II of this essay shows the attack of Scalia and Garner

9. See James R. Maxeiner, Costs of No Codes, 31 Miss. COLLEGE L. REv. 363 (2013).

10. SCALIA \& GARNER, READING LAW, supra note 1, at 9 ("We believe that our effort is the first modern attempt, certainly in a century, [citing to Henry Campbell Black, Handbook on the Construction and Interpretation of the Laws (2d ed. 1911)] to collect and arrange only the valid canons (perhaps a third of the possible candidates) and to show how and why they apply to proper legal interpretation."). 
on common law; Part III summarizes their textualism proposal for those not already familiar with it.

Lawyers in the United States typically identify a world of statutes with the Continental or civil law (e.g., French, German, Japanese). Part IV of this essay asks whether Scalia and Garner have created a civil law for the Age of Statutes. Part V shows how civil law systems combine textual and non-textual methods. Part VI shows how common law procedure is a barrier to such a combination.

\section{SCALIA \& GARNER: COMMON LAW-TRADITION IS THE PROBLEM}

Scalia and Garner rest Reading Law on recognition that in today's America the law consists of statutes. ${ }^{11}$ America of the $21^{\text {st }}$ century is not England of the $19^{\text {th }}$ century, where, in their view, statutes were infrequent, the law was principally judge-made, and judges took liberties with statutes that intruded on the common law in order to put through their personal ideas of public policy. In America of the $21^{\text {st }}$ century we do not welcome such judicial intrusions. "Such distortion of texts adopted by the people's

11. Cf. AnTONin SCALIA, Common-Law Courts in a Civil-Law System: The Role of United States Federal Courts in Interpreting the Constitution and Laws, in A MATTER OF INTERPRETATION: FEDERAL COURTS AND THE LAW 3, 13 (Amy Gutmann ed., Princeton Univ. Press 1997) ("We live in an age of legislation, and most new law is statutory law. . . The lion's share of the norms and rules that actually govern... the country [come] out of Congress and the legislatures.') [hereinafter Scalia, Common-Law Courts in a Civil-Law System]; Antonin Scalia, Review of Steven D. Smith's Law's Quandary, 55 CATH. U.L. REV. 687, 689 (2006) [hereinafter Scalia, Review of Law's Quandary]:

As interesting as Smith's analysis is, it essentially addresses a legal system that is now barely extant, the system that Holmes wrote about: the common law. That was a system in which there was little legislation, and in which judges created the law of crimes, of torts, of agency, of contracts, of property, of family and inheritance. And just as theories such as the Divine Right of Kings were necessary to justify the power of monarchs to make law through edicts, some theory was necessary to justify the power of judges (as agents of the King) to make law through common-law adjudication. That theory was the 'brooding omnipresence' of an unwritten law that the judges merely 'discovered.' ... [I]t is a rare case [today] that does not involve interpretation of an enacted text. 
elected representatives is," Scalia and Garner say, "undemocratic." 12

Yet some American judges refuse to abandon "the ancient judicial prerogative of making the law." They prefer to "improvis[e] on the text to produce what they deem socially desirable results. ... [In their lawmaking these] judges are also prodded by interpretative theorists. These are the legal realists, who have "convinced everyone that judges do indeed make law" and do not simply apply it."13

Scalia and Garner reject the claim of these "interpretative theorists" that courts are "better able to discern and articulate basic national ideals than are the people's politically responsible representatives." 14 The result, they see, of judges straying from their function of applying law-when judges "overreach" and "fashion law" rather than fairly derive it from governing texts-is that they make law uncertain, create inequality of application, undermine democracy, and politicize themselves and their offices.

Scalia and Garner are bold to take on the common law tradition; they did not have to. They could have attributed the problems they discuss to "the desire for freedom from the text, which enables judges to do what they want." 15 Instead of timidity, they show courage. They target as principal culprit the common law mindset that the nation's law professors teach. Perhaps they

12. SCALIA \& GARNER, READING LAw, supra note 1, at 3. See also Scalia, Review of Law's Quandary, supra note 11, at 687-689 ("[A democracy is] quite incompatible with the making (or the "finding') of law by judges ...").

13. SCALIA \& GARNER, READING LAW, supra note 1, at 4-5.

14. Id. at 4 (quoting ThOMAS C. GREY, Do WE HAVE AN UNWRITTEN CONSTITUTION, STANFORD LEGAL ESSAYS 179, 182 (1975)). The present poor perception of Congress tends to support the conclusions of the theorists, at least in practice, if not in theory. For current criticisms see, e.g., Symposium: The Most Disparaged Branch: The Role of Congress in the Twenty-First Century, 89 BOSTON U.L. REV. 331-870 (2009); LAWRENCE LESSIG, REPUBLIC LOST: HOW MONEY CORRUPTS CONGRESS-AND A Plan TO STOP IT (Twelve 2011); ThOMAS E. MANN \& NORMAN J. ORNSTEIN, THE BROKEN BRANCH: How CONGRESS is FAILING AMERICA AND How to GET IT BACK ON TraCK (Oxford Univ. Press 2006).

15. SCALIA \& GARNER, READING LAW, supra note 1, at 9. 
perceive that without disarming the common law tradition, their proposal will suffer the same fate as the few codes that were adopted in the United States in the $19^{\text {th }}$ century: death by judicial interpretation. $^{16}$

Scalia and Garner do not nip at the edges of the common law; they attack it head on and try to root out its most important manifestations. So even before they get to the canons of construction, they lob a nuclear artillery shell on the whole idea:

American legal education has long been devoted to the training of common-law lawyers, and hence common-law judges. What aspiring lawyers learn in the first, formative year of law school is how to discern the best (most socially useful) answer to a legal problem, and how to distinguish the prior cases that stand in the way of that solution. Besides giving students the wrong impression about what makes an excellent judge in a modern, democratic, textbased legal system, this training fails to inculcate the skills of textual interpretation.

Can this be most conservatives' favorite judge speaking? Is he ready to toss into the dustbin of history common law thinking? Yes, he is. Elsewhere, Scalia affirms that he objects to the common law "mind-set that asks, "What is the most desirable resolution of this case, and how can any impediments to the achievement of that result be evaded?",18

In an earlier essay Scalia colorfully explains how the American image of the great judge works against good judging in a modern state. So he writes:

[T]his system of making law by judicial opinion . . . is what every American law student, every newborn American lawyer, first sees when he opens his eyes. And

16. See Scalia, Common-Law Courts in a Civil-Law System, supra note 11, at 11 "The nineteenth-century codification movement espoused by Rantoul and Field was generally opposed by the bar, and hence did not achieve substantial success, except in one field: civil procedure, the law governing the trial of civil cases.").

17. SCALIA \& GARNER, READING LAW, supra note 1 , at 7. 13.

18. Scalia, Common-Law Courts in a Civil-Law System, supra note 11, at 
the impression remains for life. His image of the great judge - the Holmes, the Cardozo - is the man (or woman) who has the intelligence to discern the best rule of law for the case at hand and then the skill to perform the brokenfield running through earlier cases that leaves him free to impose that rule: distinguishing one prior case on the left, straight-arming another on the right, high-stepping away from another precedent about to tackle him from the rear, until (bravo!) he reaches the goal-good law. That image of the great judge remains with the former law student when he himself becomes a judge, and thus the commonlaw tradition is passed on. ${ }^{19}$

This is not the image of a modest judge who applies statutes to facts. $^{20}$

In a nutshell, Scalia and Garner object to the common law ideal that judges should mold the law to fit the facts, rather than take the law as a legislative given and apply it. ${ }^{21}$ To undercut that ethos, they challenge specific common law traditions in treating statutes.

Canons of strict construction of statutes. Scalia and Garner take on the old common law prejudices against statutes incorporated in the traditional canons that they mostly seek to resuscitate. They expose the false "notion that words should be strictly construed." Instead, citing Justice Story, they identify that what is needed is "reasonableness, not strictness, of interpretation." 22 They reject, as "a relic of the courts' historical hostility to the emergence of statutory law," the old canon that statutes in derogation of the common law are to be strictly construed. Instead, they say, "The better view is that statutes will not be interpreted as changing the common law unless they effect the change with clarity."23

19. Id. at 9 .

20. See James R. Maxeiner, Imagining Judges that Apply the Law: How They Might Do It, 114 PENN ST. L. REV. 469 (2009).

21. See generally Richard B. Cappalli, At the Point of Decision, The Common Law's Advantage over the Civil Law, 12 TEMP. INT'L \& COMP. L. J. 87 (1998).

22. SCALIA \& GARNER, READING LAW, supra note 1, at 355.

23. Id. at 318. Story, too, felt the need to moderate rather than terminate the canon. See EnCYCLOPEDIA AMERICANA, supra note 7, at 584 ("In all cases of a 
Statutory stare decisis. Scalia and Garner boldly challenge, as inconsistent with textualism, the essential doctrine of the common law, stare decisis, i.e., that common law courts follow their past decisions and that inferior courts are bound to follow decisions of superior courts. In the course of the $19^{\text {th }}$ century, American courts began to apply stare decisis, not only to decisions based on the common law, but to decisions construing statutes ("statutory stare decisis" or "statutory precedent"). Some appellate courts take that principle further in order to use interpretation of statutes as opportunity to make law; they create legal uncertainty that Scalia and Garner decry. Lower courts, in following statutory precedents, turn their attention away from the text that they are to apply, to the appellate court's interpretation of the text; they devalue the statute itself. $^{24}$

Scalia and Garner reject statutory stare decisis. The text controls. Thus, they say, "good judges dealing with statutes do not make law. Judges deciding cases do not 'give new content' to the statute, but merely apply the content that has been there all along, awaiting application to myriad factual scenarios." 25 What they do is considerably more modest than making law: "a court's application of a statute to a 'new situation' can be said to establish the law applicable to that situation-that is, to pronounce definitely whether and how the statute applies to that situation. But establishing this retail application is [not] 'creating law,' 'adapt[ing] legal doctrines,' and 'giv[ing] them new content.",26

doubtful nature, the common law will prevail, and the statute not be construed to repeal it.").

24. On statutory stare decisis, see Peter L. Strauss, The Common Law and Statutes, 70 Colo. L. REV. 225, 231, 244-245 (1999); James R. Maxeiner, Thinking Like a Lawyer Abroad: Putting Justice into Legal Reasoning, 11 WASH. U. Global STUd. L. Rev. 55, $82-83$ (2012) [hereinafter Maxeiner, Thinking Like a Lawyer Abroad].

25. SCALIA \& GARNER, READING LAW, supra note 1, at 5. [Emphasis in original, quotation and citations omitted].

26. Id. 
As much as Scalia and Garner would like to throw out statutory stare decisis altogether, they cannot quite bring themselves to do so. They end their book condemning it, yet acknowledging dependence on it:

Stare decisis . . . is not a part of textualism. It is an exception to textualism (as it is to any theory of interpretation) born not of logic but of necessity. Courts cannot consider anew every previously decided question that comes before them. Stare decisis has been a part of our law from time immemorial, ${ }^{27}$ and we must bow to it. All we categorically propose here is that, when a governing precedent deserving of stare decisis effect does not dictate a contrary disposition, judges ought to use proper methods of textual interpretation. If they will do that, then over time the law will be more certain, and the rule of law will be more secure. $^{28}$

If truth be told, here Scalia and Garner are bowing to a different necessity than convenience. ${ }^{29}$ It is a necessity of political acceptance: their originalism-based proposals will be dead on arrival if they are seen "to turn the clock back" to produce a “"radical purge' of society's settled practices and beliefs.",30

27. The Supreme Court itself sometimes puts aside Holmes' aphorism and decides, because, that's the way we always have done it. See, e.g., Flood v. Kuhn, 407 U.S. 258 (1972) (baseball exemption from antitrust law); Burnham v. Superior Court, 495 U.S. 604 (1990) (tag rule of civil procedure); Calero-Toledo v. Pearson Yacht Leasing Co., 416 U.S. 663 (1974) (civil forfeiture of innocent owner's yacht).

28. SCALIA \& GARNER, READING LAW, supra note 1, at 413-414.

29. Civil law systems get along fine interpreting statutes without binding precedents. 87:

30. SCALIA \& GARNER, READING LAW, supra note 1, at 411. Accord, id. at

A frequent line of attack against originalism consists in appeal to popular Supreme Court decisions that are asserted based on a rejection of original meaning. We do not propose overruling all those decisions. Our prescriptions are for the future. For the past, we believe in the doctrine of stare decisis, which will preserve most of the nonoriginalist holdings on the books. Which ones will fall depends on several factors. [FN 38. See infra at 411-14] Stare decisis is beyond the scope of our discussion here, but it is germane to the present point that the relevant factors include the degree of public acceptance. 
IV. SCALIA \& GARNER: [PURE] TEXTUALiSM IS THE SOLUTION

Scalia and Garner propose textualism as the solution to the problem of controlling judges who take liberties with texts. It is to be the generally agreed on approach to the interpretation of legal texts. Textualism will save Americans from politicized judges who impair the predictability of judicial decisions, give unequal treatment to similarly situated litigants, weaken our democratic process and distort our governmental system of checks and balances. It is not too late to restore a strong sense of judicial fidelity to texts. ${ }^{31}$

Textualism, Scalia and Garner say, is not a novel approach, but "the oldest and most commonsensical interpretative principle.",32 They define textualism to be "the doctrine that the words of a governing text are of paramount concern, and what they convey in their context is what the text means.",33

Scalia and Garner assert that if one is not a textualist, one must be a "non-textualist." Non-textualists come in a variety of species, the two most common of which are purposivists and pragmatists (also called "consequentialists" by Scalia and Garner). Both purposivism and pragmatism "liberate" judges from the constraints of rules. Purposivism gives interpreters the opportunity to change texts according to what they perceive to be the purposes of statutes. Scalia and Garner pigeon-hole purposivism as a license to manipulate. It produces uncertainty. Pragmatism allows interpreters to give texts "sensible, desirable results." The problem: "people differ over what is sensible and what is desirable." According to Scalia and Garner, the people have given those decisions to elected representatives. ${ }^{34}$

Scalia and Garner are concerned with controlling judges; they do not dwell on obvious benefits that textualism has for guiding

31. SCALIA \& GARNER, READING LAW, supra note 1 , at xxvii.

32. Id. at 15 .

33. Id. at 441 .

34. Id. at 22 . 
society generally. Most applications of law are self-applications. Subjects consider what they know of the law and fit themselves within it. If law is easily manipulated, or simply uncertain, those who skirt the law have an invitation to do so: So sue me! Those who scrupulously follow the law are dissuaded from taking action they might otherwise take: It's too risky! ${ }^{35}$

The principal elements of textualism in its basic form are:

The words of the statute are paramount. A textualist extracts the meaning of the text from the words of the text itself and nothing more. ${ }^{36}$

The statute is to be given a fair reading, neither strict, nor liberal. A fair reading is: "The interpretation that would be given to a text by a reasonable reader, fully competent in the language, who seeks to understand what the text meant at its adoption, and who considers the purpose of the text but derives purpose from the words actually used." 37

The statute is to be understood objectively. The interpreter is to look to the words expressed in the text and not to the unexpressed thoughts of legislators. Collective bodies have no intent. ${ }^{38}$

If the plain meaning of a statute is clear, it should be followed, unless absurd. An unambiguous text is to be applied by its terms without recourse to policy, historical arguments or other matter extraneous to the text. The legislature has stated what the law is; it is not for law-appliers to overrule those decisions.

Where more than one interpretation is possible, only permissible meanings are to be considered. Words and sentences are not to be given meanings that they will not bear. ${ }^{39}$

35. See generally James R. Maxeiner, Legal Indeterminacy Made in America: U.S. Legal Methods and the Rule of Law, 41 VALPARAISO L. REV. 517 (2006).

36. SCALIA \& GaRNER, READING LAW, supra note 1, at 441.

37. Id. at 428 . Basic textualism does not seem to require, however, as pure textualism does, that the meaning be fixed as that at the time of adoption.

38. Id. at 391 .

39. Id. at 31 . 
Where more than one interpretation is permissible, principles of interpretation, many called "canons of construction", guide decision-makers. ${ }^{40}$ These principles are not absolute; instead, they interrelate. $^{41}$

It is at this point, when the meaning of the text is ambiguous, ${ }^{42}$ that pure textualism diverges from basic textualism. In basic textualism, the interpreter might resort to any number of interpretative tools. In pure textualism, according to Scalia and Garner, interpretation "begins and ends with what the text says and fairly implies." 43 It limits interpretation to principles based on language and historical meaning (but not legislative history). Scalia and Garner allow some systemic arguments. But they exclude other interpretive arguments, including purposive, pragmatic, and most equitable arguments.

Principal additional characteristics of pure textualism are:

Words must be given the meaning they had when the text was adopted. $^{44}$ This is Scalia and Garner's preferred meaning of originalism. $^{45}$

40. Id. at 32 .

41. Id. at 59. This rejects the approach many common lawyers would like to see, i.e., that canons of construction are like rules that are binding. Presumably there would be a mandatory and therefore predictable construction, which would facilitate presenting cases in court. See generally, Sydney Foster, Should Courts Give Stare Decisis Effect to Statutory Interpretation Methodology?, 96 GEO. L.J. 1863 (2008); Abbe R. Gluck, The States as Laboratories of Statutory Interpretation, Methodological Consensus and the New Modified Textualism, 119 YALE L.J. 1750 (2010); Abbe R. Gluck, Statutory Interpretation Methodology as "Law": Oregon's Path-Breaking Interpretive Framework and Its Lessons for the Nation, 47 WILLAMETTE L. REV. 539 (2011); Gary O'Connor, Restatement (First) of Statutory Interpretation, 7 N.Y.U. J. LEGIS. \& PUB. POL'Y 333 (2003); Nicholas Quinn Rosenkranz, Federal Rules of Statutory Interpretation, 115 HARV. L. REV. 2085 (2002). It is, however, consistent with Supreme Court precedent. See Conn. Nat'l Bank v. Germain, 503 U.S. 249, 253 (1992) ("no more than rules of thumb that help courts determine the meaning of legislation"); Chickasaw Nation v. United States, 534 U.S. 84, 94 (2001) (canons of construction are not "mandatory rules" but rather are "guides that need not be conclusive").

42. Note that here Scalia and Garner are dealing with ambiguity in the language of the text, and not ambiguity in how the text applies to a particular case.

43. SCALIA \& GARNER, READING LAW, supra note 1 , at 16.

44. SCALIA \& GARNER, READING LAW, supra note 1, at 78. 
Legislative history is not an acceptable argument in statutory interpretation. Legislative bodies are collectives. Who is to say that all of the legislators had the same understanding?

Doing justice is not an acceptable basis for statutory interpretation. Judges must be faithful to the law. ${ }^{46}$ Scalia and Garner follow Blackstone: "law, without equity, though hard and disagreeable, is much more desirable for the public good, than equity without law." 47

The meaning of a statute is not to be found in the social, political or economic objectives of the law. ${ }^{48}$

Judges are not to supply law for omitted cases. Legislation is for the legislature. For judges to correct the statute violates principles of separation of powers. ${ }^{49}$

This is the prescription of Scalia and Garner of a modern law for the Age of Statutes.

45. Id. at 435 .

46. Id. at 347. Id. at 348:

The problem is that although properly informed human minds may agree on what a text means, human hearts often disagree on what is right. That is why we vote (directly or through our representatives) on what the law ought to be, but leave it to experts of interpretation called judges to decide what an enacted law means. It is doubtless true, as a descriptive matter, that judges will often strain to avoid what they consider an unjust result. But we decline to elevate that human tendency to an approved principle of interpretation.

The soundest, most defensible position is one that requires discipline and self-abnegation. If judges think no further ahead than achieving justice in the dispute now at hand, the law becomes subject to personal preferences and hence shrouded in doubt. It is age-old wisdom among mature, experienced legal thinkers that procedure matters most: how things should be done, as opposed to what should be done. And for judges the 'how' is fidelity to law. But it is a hard lesson to learn, and harder to follow.

47. SCALIA \& GARNER, READING LAW, supra note 1, at v (unnumbered in book)

48. Id. at 438 .

49. Id. at $349-350$. 


\section{Is TeXtualism A Civil LAW For THE Age of Statutes?}

Is textualism a civil law for the Age of Statues? Scalia and Garner invite us to ask that question when they claim the mantel of consistency with "the best legal thinkers" and when they invoke Bentham and Continentals such as Gadamer, Kelsen, Locke, Montesquieu and Thibaut. The title of an earlier essay by Scalia practically begs us to ask it: Common-Law Courts in a Civil-Law System: The Role of United States Federal Courts in Interpreting the Constitution and Laws. ${ }^{50}$ Is Scalia, who is better known for opposing references to foreign law than promoting them, creating his own civil law? In Reading Law, he and Garner peripherally pay tribute to civil law methods when they quote Karl Llewellyn (albeit in a footnote): "It is indeed both sobering and saddening to match our boisterous ways with a statutory text against the watchmaker's delicacy and care of a . . Continental legal craftsman." 51

Textualism shares much with civil law approaches. Its basic model is mainstream the world over. It has been used, as Scalia and Garner say, for centuries. In textualism, the written law governs. Pure textualism, however, has more in common with past manifestations of civil law methods than with modern ones. In Germany, for example, its closest cousin is the Prussian Code of 1794, and not any later code.

This observation is not condemnation, but constructive criticism. Scalia and Garner are making up for a deficit of two centuries in dealing with statutes. While Americans have made little progress with written law since the path-breaking Constitution, ${ }^{52}$ civil law countries have made much. ${ }^{53}$ Scalia and

50. In SCALIA, A MATTER OF INTERPRETATION, supra note 11, at 3-47.

51. SCALIA \& GARNER, READING LAW, supra note 1 , at 8 , n. 16 citing to Karl Llewellyn, THE COMmon LAW Tradition: DeCIDING APPEALS 380 (1960).

52. Cf. Charles Abernathy, The Lost European Aspirations of US Constitutional Law, in 24. FEBRUAR 1803, DIE ERFINDUNG DER VERFASSUNGSGERICHTSBARKEIT UND IHRE FOLGEN 37 (Werner Kremp, ed. 2003): 
Garner have released, what we might call, U.S. Textualism Version 1.0.

Here in Part IV we consider what basic textualism shares with civil law methods, and second, what sets pure textualism apart from contemporary civil law methods. For practical reasons, we limit our consideration to one of the world's two leading civil law jurisdictions, that of Germany, and mention only incidentally that of the other, France. ${ }^{54}$

\section{A. Textualism is Civil}

Basic textualism as stated by Scalia and Garner is consistent with German approaches to statutes. In Germany, statutes are the

Despite its European origins, [the U.S.] legal constitutional tree has grown into a very strange hybrid, a tree with continental European roots but an increasingly common-law superstructure of branches, trunks, and leaves. Despite repeated attempts by some Supreme Court justices, the continental code-law tradition has been unable to win a majority at the Supreme Court for many decades.

53. See, e.g., Reinhard Zimmermann, Statute Sunt Stricte Interpretanda? Statutes and the Common Law: A Continental Perspective, 56 CAMBRIDGE L.J. 315, 315-316 (1997) [hereinafter Zimmermann, Statutes] ("An English colleague has suggested that "civilian lawyers regard our case law with admiration and our statute book with despair.' It may therefore be appropriate to remind ourselves that civilian lawyers once struggled with the same kind of problem that is being addressed today."); id. at 321 (in Germany, following adoption of the 1949 constitution, in statutory interpretation there has been "a considerable advance in legal culture.").

54. For the convenience of readers who may not read German and yet wish to follow the argument further, I largely cite English-language works by leading German scholars. In particular, I cite the one standard work on German legal methods which has been translated into English: REINHOLD ZIPPELIUS, AN INTRODUCTION TO GERMAN LEGAL METHODS (Kirk W. Junker \& P. Matthew Roy trans., 10th ed., Carolina Acad. Press 2008) [hereinafter ZIPPELIUS]. The first edition appeared under the title EINFÜHRUNG IN DIE JURISTISCHE METHODENLEHRE (1st ed. 1971); the most recent is under the title JURISTISTISCHE METHODENLEHRE: EINE EINFÜHRUNG (10th ed. 2006). The other classic students' text is KARL ENGISCH, EINFÜHRUNG IN DAS JURISTISCHE DENKEN (1st ed. 1956; 10th ed., Thomas Würtenberger \& Dirk Otto eds., 2005). The classic academic text is KARL LARENZ, METHODENLEHRE DER RECHTSWISSENSCHAFT (1st ed. 1960; 6th ed. 1991; 4th condensed study ed. with Claus-Wilhelm Canaris, 2009). The global comparative work is WOLFGANG FIKENTSCHER, METHODEN DES RECHTS IN VERGLEICHENDER DARSTELlung (5 vols., Mohr 1975-1977). 
principal form of law. If their application is clear, they must be followed, unless they are invalid (e.g., unconstitutional). Democracy and the rule of law demand no less. ${ }^{55}$

The words of the text are paramount. In Germany, the words of the text are of paramount concern; they convey what the text means. The statute - das Gesetz-is the fundamental concept of all law. When an American says, "we have a rule of law, not of men," a German says, "statutes, not men, govern." 56

Statutes must be followed unless the result is irrational or unjust. $^{57}$ No one-other than the Constitutional Court-is permitted to put a valid law out-of-force. To allow a judge, a government official or a subject of the law not to apply the law is to deny that Germany is a democratic, rule-of-law state.

Statutes are interpreted objectively. Statutes should be understood objectively, that is, according to "the intention of the statute itself." ${ }^{, 58}$ An objective interpretation seeks an understanding "familiar to the mindset of a wide number of people." attempt to recreate a subjective intent of those who took part in the legislative process. ${ }^{60}$ Their individual wills are difficult to determine and are unlikely to be in harmony with one another. ${ }^{61}$

Words have a range of meanings. Statutes and other legal rules put ideas into words. Words are, however, ambiguous; they may refer to more than one concept. Words that describe facts seldom

55. Winfried Brugger, Concretization of Law and Statutory Interpretation, 11 TuL. EuR. \& CIV. L.F. 207, 208 (1996) [hereinafter Brugger, Concretization of Law].

56. WALTER LEISNER, KRISE DES GESETZES: DIE AUFLÖSUNG DES NORMENSTAATES 5 (Duncker und Humblot 2001) ("Nicht Menschen herrschen-Gesetze gelten."). See also James R. Maxeiner, Legal Certainty: A European Alternative to American Legal Indeterminacy?, 15 TULANE J. INT'L \& COMP. L. 541, 558 (2007) [hereinafter Maxeiner, Legal Certainty].

57. Winfried Brugger, Legal Interpretation, Schools of Jurisprudence, and Anthropology: Some Remarks from a German Point of View, 42 AM. J. CoMP. L. 395, 401 (1994) [hereinafter Brugger, Legal Interpretation]. See also Brugger, Concretization of Law, supra note 55.

58. ZIPPELIUS, supra note 54, at 30.

59. Id. at 32 .

60. Id. at 32 .

61. Id. at 33 . 
carry the same meaning for everyone. A given word has a "range of meanings." 62 To go outside the range of possible meanings creates a legitimacy problem; ${ }^{63}$ it is to take over the function reserved to the legislature. ${ }^{64}$

Where there is more than one meaning within a range, principles of interpretation guide interpretation. Where the principles of the common law, the canons, are numerous and particular, the principles of German law are few and general. Four approaches are dominant: ${ }^{65}$ (1) grammatical, (2) historical, (3) systemic, and (4) purposive (teleological). ${ }^{66}$ The classical criteria of interpretation, while they facilitate finding the correct interpretation, do not give license to go outside the range of possible meanings of a statute's words. "All further efforts at interpretation proceed on the basis of a word's possible meaning. These efforts are carried out within a range of meaning that is permissible according to linguistic usage (possibly circumscribed by legal definitions)." ${ }^{, 67}$ Every approach must, however, "respect the outer bounds of grammatical analysis., ${ }^{68}$

62. Id. at $62-66$.

63. Id. at 96 .

64. Id. at 72 .

65. Zimmermann, Statutes, supra note 53, at 320.

66. Id. at 60. See also id. at 320 (" (1) the literal meaning of the words or the grammatical structure of a sentence, (2) the legislative history, (3) the systematic context and (4) the design, or purpose, of a legal rule." [citing 1 FRIEDRICH CARL VON SAVIGNY, SYSTEM DES HEUTIGEN RÖMISCHEN RECHTS 206 (1840) (translated as SYSTEM OF THE ROMAN LAW (William Holloway trans., 1979) (1867)]); Brugger, Concretization of Law, supra note 55, at 234 (listing in table form what four methods more fully described in the article, i.e., "I. textual interpretation 'what is specifically said'; II. Contextual interpretation 'what is said in context'; III. Historical interpretation 'what was willed'; IV. Teleological interpretation "what is the purpose"'); Robert Alexy \& Ralf Dreier, Statutory Interpretation in Germany, in INTERPRETING STATUTES: A COMPARATIVE STUdy 73, 82-89 (D. Neil MacCormick \& Robert S. Summers eds., Ashgate 1991) (giving a somewhat different breakdown of approaches).

67. ZIPPELIUS, supra note 54, at 60; ("feasible meanings" at 67).

68. Brugger, Legal Interpretation, supra note 57, at 400; See also Brugger, Concretization of Law, supra note 55. 
Of these four approaches, the most common is the purposive, which includes an equitable approach. ${ }^{69}$

Variations and additions are sometimes suggested, particularly since the adoption of the Basic Law in 1949 (with respect to fundamental rights and the structure of the state), and the accession in 1958 to what is now the European Union (particularly with respect to harmonization of law). Whether constitutional texts should receive different treatment is debated, with no clear resolution.

Which interpretation prevails is argumentative. There is no hierarchy in applying the approaches. An interpreter may make use of all approaches and choose the approach or approaches that seem most convincing in a particular case. ${ }^{70}$ It is said that "the decisive point of reference is the interpreter's notion of a result that, according to the 'independent function' or value of the pertinent legal provision, must be the correct one." 71

\section{B. Pure Textualism is Uncivil}

Pure textualism was the approach of the Prussian Civil Code of 1794. Its section 46 of the Introductory Part prohibited judges from going beyond the text. If the judge could not get the meaning from the text, he was to refer the legal question to a special code commission. ${ }^{72}$ The approach was regarded as monstrous.

Pure textualism in Germany today would be anathema. Zimmermann writes that "[o]n the Continent we have managed to

69. Zimmermann, Statutes, supra note 53, at 320; Reinhard Zimmermann, Characteristic Aspects of German Legal Culture, in INTRODUCTION OF GERMAN LAW 1, 24-25 (J. Zekoll \& M. Reimann eds., 2d ed., Wolters Kluwer 2005).

70. Brugger, Legal Interpretation, supra note 57, at 402.

71. Id. at 397.

72. "Bey Entscheidungen streitiger Rechtsfälle darf der Richter den Gesetzen keinen andern Sinn beylegen, als welcher aus den Worten, und den Zusammenhänge derselben, in Beziehung auf den streitigen Gegenstand, oder aus den nächsten unzweifelhaften Grïnde des Gesetzes, deutlich erhellt." Allgemeines LANDRECHT FÜR DIE PREubischen StaAten von 1794, TeXtausgabe mit EINER EINFÜHRung von HANS HATTEHAuer 58 (2d ed., Luchterhand 1994). 
shake off the self-imposed fetters of a literalist approach to statutory interpretation." 73 In Germany, the most practiced method is said to be purposivism: ${ }^{74}$ i.e., poison to Scalia and Garner. Their panacea, the historical, it is said in Germany, "generally serves only as a secondary, supplementary way of clarifying a rule's meaning.",75

Some basic principles of modern German interpretation are opposed to Scalia and Garner's pure textualism. For example:

Statutes should be interpreted according to ideas of the present ("living interpretation"). They are not to be limited ideas controlling at the time they were adopted. ${ }^{76}$ "The basis of legitimacy of law to be applied today does not lie in the past; it lies in the present. . . . For the present it does not matter under whose authority the statute was enacted, but rather under whose authority it lives on today." 77

Certain legislative history is an acceptable argument in statutory interpretation. German legislative procedures differ from American. Most statutes are presented to the legislature in draft form for debate. The debates themselves are not tools of interpretation, but one may rely on the formal justifications provided with the draft statutes to understanding the meaning of the words used in the drafts.

73. Zimmermann, Statutes, supra note 53, at 320.

74. Id. at 320 .

75. Brugger, Legal Interpretation, supra note 57, at 401.

76. ZIPPELIUS, supra note 54, at 34.

77. $I d$. at 34-35. While considerations of legitimacy and of justice demand a living interpretation, Zippelius teaches that considerations of separation of powers (and we might add, of legal certainty), require that "a change in meaning must not only keep itself within the possible meanings of the text of a legal norm, but also, where possible, within that very range of meaning that the purpose of the legislation leaves open for honing in on." Id. at 36. German ministries of justice are responsible for removing from the statute books obsolete laws. Some newer German laws as adopted automatically expire. See ORGANISATION FOR ECONOMIC CO-OPERATION AND DEVELOPMENT, BETTER REGULATION IN EUROPE: GERMANY, 114-15 (2010), available at http://www.oecd.org/document/63/0,3746, en $2649 \quad 34141 \quad 4504889511111$. 00.html (last visited 04/23/13). 
Doing justice is an acceptable basis for statutory interpretation. The judge asks: "Which of the possible 'justifiable' interpretations, according to the rules of the art, lead to the most just solution?"78

The meaning of a statute may be found in the social, political or economic objectives of the law.

Judges may-exceptionally-supply law for omitted cases ${ }^{79}$ In filling in gaps, it is appropriate to consider societal goals, system consistency and justice. ${ }^{80}$ Gap-filling to achieve material justice raises the question as to whether supplementation should be done politically, for the future by the legislature, or according to existing law, by judges. ${ }^{81}$

The German system poses a challenge to Scalia and Garner: it practices textualism, but rejects its pure form and takes the poison of purposivism. It seeks to do justice in individual cases or to provide pragmatic solutions. One would expect that Germany would be a cesspool of renegade judges imposing their individual ideas of justice; yet the German system is not. To the contrary, it is known for separating policy and law, and stressing legal certainty. How are we to explain this enigma? That is the topic of Part V.

78. ZIPPELIUS, supra note 54 at 86.

79. $\quad I d$. at 17.

80. Id. at 97.

81. Id. at 91:

By supplementing the law, the judge is functioning in a manner reserved for the legislature under a system of separation of powers. The legislature is in a better position than a court to tackle questions of legal supplementation-considerations that are often highly political in nature - and it does so with more democratic legitimacy, particularly with respect to the necessary debate and conversation with the public. 


\section{IN MODERN CIVIL LAW TEXTUALISM AND NON-TEXTUALISM COEXIST}

Textualism and non-textualism coexist in modern civil law systems. They must, if law is to do its job and balance justice, policy and legal certainty. ${ }^{82}$

\section{A. Law in Time Requires that Textualism and Non-Textualism Must Coexist}

Legislatures enact rules that apply generally today and into the future. The limits of our ability to know the present, and to foresee the future, limit the ability of legislatures to prescribe legal answers to future questions. ${ }^{83}$ Often rules set outer limits of their application without prescribing exact decisions. They leave precise decisions to those who apply the law. They may provide criteria or procedures for decisions.

Textualism defines the outer limits of decisions. Nontextualism determines how those rules are applied within the limits set. The outer limits provide one level of legal certainty to those subject to the law; ${ }^{84}$ confidence in how those applying the law will do so within those outer limits can add a second level of legal certainty. The laws, written by the legislature, provide general rules intended to achieve justice and policy goals. Those charged with applying the law, within its limits, are responsible for reaching decisions that not only comply with the letter of the law, but that also fulfill the goal of law to achieve justice and good policy.

82. Cf. JAMES R. MAXEINER, POLICY AND METHODS IN GERMAN AND AMERICAN ANTITRUST LAW: A COMPARATIVE STUdY 12 (Praeger 1986) [hereinafter MAXEINER, POLICY AND METHODS IN GERMAN AND AMERICAN ANTITRUST LAW]; Brugger, Concretization of Law, supra note 55, at 209-217.

83. See James R. Maxeiner, Legal Certainty, supra note 56, at 554-55; Brugger, Concretization of Law, supra note 55, at 224-30.

84. One might say that the law binds negatively. See MAXEINER, POLICY AND METHODS IN GERMAN AND AMERICAN ANTITRUST LAW, supra note 82. 
As we have seen, the drafters of the Prussian Code of 1794 sought to tie judges strictly to texts. If the text did not deliver the answer, then judges were to refer questions to a legislative commission. The drafters of the French Codes of 1804 charted a better and more modern course. They sought to limit judges with textualism, but to guide them with what Scalia and Garner call non-textualism. So Portalis, the drafter of the Code Civil, wrote in an essay introductory to his code: "When the law is clear, it must be heeded; when it is unclear, the provisions must be further elaborated. If there is no law, then custom or equity must be consulted. Equity is the return to natural law when positive laws are silent, contradictory or vague." 85 In the modern civil law world, textualism and non-textualism can and must coexist.

Portalis eloquently stated how the phenomenon of law in time requires that texts cannot be unchanging:

Whatever one might do, positive laws could never entirely replace the use of natural reason in life's affairs. The needs of society are so varied, the communication of men so active, their interests so numerous, and their relationships so far reaching, that the lawmaker cannot possibly foresee all.

The very matters on which he fixes his attention involve a host of particulars that escape him or are too contentious and too volatile to be the subject of a statutory enactment. Moreover, how does one bind the action of time? How to go against the course of events, or the imperceptible inclination of morals? How to know and calculate in advance what experience alone can reveal? Can foresight ever extend to things beyond the reach of thought?

A code, however complete it may seem, is no sooner

85. PRELIMINARY ADDRESS ON THE FIRST DRAFT OF THE CIVIL CODE PRESENTED IN THE YEAR IX BY MESSRS. PORTALIS, TRONCHET, BIGOTPRÉAMENEU AND MALEVILLE, MEMBERS OF THE GOVERNMENT-APPOINTED COMMISSION (1801), translated and available at http:/www.justice.gc.ca/eng/pi licg-gci/code/index.html (last visited 4/26/13); see the original French Portalis, Tronchet, Bigot-Préameneu \& Maleville, Discourse préliminaire, in 1 J. LOCRÉ, La Législation Civile, Commerclale et Criminelle de LA FranCE 251, 255-72 (1827); see also ARTHUR TAYLOR VON MEHREN \& JAMES RUSSELL Gordley, The Civil LAw System 54-55 (2d ed., Little, Brown \& Co. 1977) (translation of an extract). 
finished than thousands of unexpected questions present themselves to the magistrate. For these laws, once drafted, remain as written. Men, on the other hand, never rest. They are always moving; and this movement, which never ceases and whose effects are variously modified by circumstances, continually produces some new fact, some new outcome. ${ }^{86}$

How are Scalia and Garner and other proponents of pure textualism and originalism to answer this wisdom? It is simplistic for them to say that the legislature should amend the laws. It is wishful thinking and reminiscent of the failed Prussian legislative commission to think that we might, as some scholars have recently suggested, add procedures to refer disputed questions back to legislatures. $^{87}$

Civil law systems can read law combining textualism and nontextualism because civil law methods of writing and applying law facilitate doing so. Statutes and procedures anticipate that appliers will be making equity and policy decisions.

\section{B. Reading Law is Doctrinal Rather than Authoritative}

In civil law systems, most instances of statutory interpretation are, in the words of Portalis which we adopt here, doctrinal and not authoritative. ${ }^{88}$ Doctrinal interpretation helps judges determine whether the facts of a particular case fall within the bounds of a statute. It consists of understanding the true meaning of statutes. The interpretation binds no future courts. Authoritative interpretation, on the other hand, settles issues and creates rules. It does bind future decisions. Authoritative interpretation ideally

86. PORTALIS, supra note 85 [unpaginated].

87. See, e.g., Amanda Frost, Certifying Questions to Congress, 101 Nw. U. L. REV. 1 (2007).

88. So Portalis wrote:

Doctrinal interpretation consists in grasping the true meaning of laws, in applying them judiciously and in supplementing them in cases where they do not apply. Can one conceive of fulfilling the office of judge without this type of interpretation?

Authoritative interpretation consists in settling issues and doubts by means of rules or general provisions. This mode of interpretation is the only one denied the judge. 
would be the exclusive prerogative of the legislature. But practical realities preclude that. Today, courts of last resort in Germany and other civil law countries issue authoritative interpretations. When interpretation is doctrinal, the integrity of the text is maintained no matter how a particular court decides in an individual case; when it is authoritative, courts, by becoming interpreters, become lawgivers. 89

Scalia and Garner, in seeking to curtail stare decisis, would make statutory interpretation largely doctrinal. They too see authoritative interpretation as lawmaking. They would limit authoritative interpretations. They say that applying law in a particular case is - at most_a "retail" making of law: "a court's application of a statute to a 'new situation' can be said to establish the law applicable to that situation-that is, to pronounce definitively whether and how the statute applies to that situation. But establishing this retail application is [not] 'creating law'. . .90

\section{Writing Law in the Age of Statutes}

Modern codes in civil law countries do not regulate comprehensively. Portalis again well-captures their methods:

The function of the statute is to set down, in broad terms, the general maxims of the law, to establish principles rich in consequences, and not to deal with the particulars of the questions that may arise on every subject.

89. John Chipman Grey in one of his books famously quoted Bishop Hoadly, not one time, but three times: "Whoever hath an absolute authority to interpret any written or spoken laws, it is He who is truly the Law-Giver to all intents and purposes, and not the person who first wrote or spoke them." JOHN ChIPMAN GReY, THe NATURE AND SOURCES OF LAW 229, 276, 369 (Columbia Univ. Press 1909).

90. SCALIA \& GARnER, REAdING LAw, supra note 1, at 5. In Germany, where interpretations of statutes are not given binding effect, Professor Fikentscher has proposed a limited binding effect in such applications, which he calls a "case norm". See Wolfgang Fikentscher, Eine Theorie der Fallnorm als Grundlage von Kodex- und Fallrecht (code law and case law), 21 ZEITSCHRIFT FÜR RECHTSVERGLEICHUNG (ZfRV) 161 (1980). 
It is left to the magistrate and the jurisconsult, fully alive to the overall spirit of laws, to guide their application.

In how closely they deal with particulars, codes vary from country to country, within each country, and even within themselves. Nevertheless, they have in common that they do not regulate every particular and that they do leave it to judges and lawyers to guide their application.

Modern statutes serve two purposes: to the extent they can, they prescribe rights and obligations. When they cannot do that, they prescribe who can create or determine rights and obligations and how they may do so. In other words, statutes structure authority.

In Germany, it is said that organization of authority is the "backbone" of a legal system's rational structure. "92 "The law [not only] . . . consists of obligations to do something or refrain from doing something, [it consists] as well as rules regulating the creation, modification and termination of behavioral norms or individual rights." 93 When we think of law, we think first of obligations, such as stopping at a red light. But its authorizations are no less important: e.g., a traffic officer may stop a motorist who the officer observes is not complying with traffic rules.

Authorizations take over when rules cannot direct solutions. Legislatures cannot anticipate all eventualities; they cannot rationally pre-determine what all outcomes will be. What they can do is to structure authority and its exercise. Then they do not try to calibrate all choices in advance. They let government officials or individuals subject to law make essential choices. Usually, when legislatures give others leeway in deciding, they do not leave decision-makers free to decide without limitation. Usually they require specific criteria or specific procedures for those choices.

91. Supra note 85 [unpaginated].

92. ZIPPELIUS, supra note 54, at 6.

93. Id. at 11 . 
They authorize law-appliers to make value decisions of justice or policy. ${ }^{94}$ Yet in all these instances, law structures decisions without claiming to command particular decisions. Although law cannot answer definitively what should be decided, it can answer who should decide using which criteria, subject to which process. ${ }^{95}$ Among the techniques modern statutes use are indefinite legal terms, general clauses and grants of discretion.

Indefinite legal concepts. Indefinite legal concepts allow for a range of meanings; they deliberately give law flexibility. "This range of meaning allows these general legal words to adapt to the wide and diverse range of legal problems and circumstances of life that the law seeks to regulate, as well as to the changing prevalent social-ethical views." 96 They permit a range of judgment to the law appliers. ${ }^{97}$ When indefinite concepts are used, there may be no "one meaning to be made from general persuasive reasons." There thus becomes a range of "justifiable decisions," although "some interpretations are more justifiable than others." 98

General clauses. A general clause is a provision that depends on an indefinite legal concept as the operative provision. German statutes use general clauses to take into account the many sides of life that do not lend themselves to definition in clearly defined

94. See MAXEINER, POLICY AND Methods In GERMAN AND AMERICAN ANTITRUST LAW, supra note 82.

95. ZIPPELIUS, supra note 54, at xii. "The interpretation and development of the law are indeed capable of being rationally structured; however, they are not completely capable of being rationally determined."

96. Id. at 66.

97. Zippelius gives as an example of room for judgment the term "forest." Is a "small, free-standing, natural pine woods with approximately 50 half-grown trees" a forest?" Suppose the requisite element for a crime of arson is setting fire to a forest. Classifying this stand of trees as a forest is for Zippelius preeminently a question of interpreting the statute and not one of subsuming the facts under the statute. In so doing, that interpretation then gives "meaning for future cases." In other words, the specific case "gives the impetus to weigh and to make precise the range of the meaning of the norm-with regard to the submitted facts of behavior." (emphasis in the original) Id. at 132.

98. ZIPPELIUS, supra note 54, at 135. 
concepts. By using general clauses, legislation need not be fragmentary, but can be gap free. ${ }^{99}$

General clauses do not permit judges to decide what they think is "fair" or in the "general welfare." 100 Instead, case groups develop in an almost common-law manner. ${ }^{101}$ Only where there are no prior decisions do judges have some freedom in reaching new solutions. ${ }^{102}$ Sometimes the legislature notes the development of these case groups and enacts them into law or introduces its own groups of cases.

Discretion. Sometimes statutes deliberately do not bind decision-makers to one correct decision, but grant them discretion to reach their own decisions based on their own responsibility and independent choice. It is used to permit a purposeful or just decision in individual cases. ${ }^{103}$ Administrative authorities are allowed to make policy-oriented decisions upon their own responsibility; they may choose on the basis of current and local interests among several possibilities. This freedom is acceptable

99. KARL ENGISCH, EINFÜHRUNG IN DAS JURISTISCHE DENKEN 124 (7th ed., Kohlhammer 1977). German indefinite legal concepts are best known in the United States through two general clauses of the German Civil Code, sections 138 and 242, which have become parts of American law through adoption in the Uniform Commercial Code (U.C.C.). BüRGERLICHES GESETZBUCH [BGB] [Civil Code] Aug. 18, 1896, RGBL 195, as amended, $\$ \S 138,242$. Section 138's U.C.C. counterpart is $\S 2-302$, which permits nonenforcement of "unconscionable" contracts or terms. U.C.C. $\$ 2-302$ (2004). Section 242 requires performance of contracts in "good faith," BGB $\$ 242$; its U.C.C. counterpart is $\S 1-304$ (formerly $\S 1-203$ ). U.C.C. $\S 1-304$. For the origin of $\S 2$ 302, see James R. Maxeiner, Standard-Terms Contracting in the Global Electronic Age, 28 YALE J. INT'L L. 109, 116-117 (2003) [hereinafter Maxeiner, Standard-Terms Contracting].

100. See Franz Wieacker, Zur rechtstheoretischen Präzisierung des $\$ 242$ $B G B$, in 2 AUSGEWÄHLTE SCHRIFTEN 195, 203 (Dieter Simon ed., Metzner 1983).

101. See Maxeiner, Standard-Terms Contracting, supra note 99.

102. Wieacker, supra note 100 , at 203 . Wieacker also notes that $\S 242$ looks to issues of individual justice and not to general welfare (policy). $I d$. at 196.

103. A common view in Germany holds that discretion in choice of legal consequences (e.g., five or ten years' imprisonment) is appropriate, but not in determination of the prerequisites for action (e.g., whether defendant committed the crime of arson). This distinction marks a difference between indefinite legal concepts and discretion: the former leaves room for judgment in the prerequisites of action, while the latter provides for freedom of action. 
because administrative authorities are politically accountable. Administrative authorities are nonetheless obligated to exercise their freedom of choice in the public interest. Relaxation of binding to statute for judicial decisions, on the other hand, is preferably limited to situations, where necessary, that permit judges to do justice in individual cases. Judges are not politically accountable; they are guaranteed independence to permit them to do justice.

\section{Applying Law in the Age of Statutes}

German procedure supports the coexistence of textualism and non-textualism. Among the ways it does this are: (i) judges and government officials know the law (iura novit curia) and are responsible for applying it to facts provided by parties ( $d a$ mihi factum, dabo tibi ius); (ii) judges and government officials must give reasoned explanations for their decisions; and (iii) judges of the intermediate level of appeal are responsible for reviewing all aspects of the decisions of courts of first instance, including the application of law to facts.

i. Judges know the law and are responsible for applying it. In the first and second instance, the focus of German judges is on whether the facts in the case fulfill the requisite elements of any legal rule. They need to know which statutes might apply and to understand those statutes well enough to know what they require. The judge is constitutionally bound to decide according to both statute and justice. Procedurally the judge is bound to clarify cases. A judge, troubled that a case may lead to a decision contrary to justice or good policy, need not twist the law to reach a good decision; he or she may better understand the facts. Intermediate appellate courts have similar obligations. ${ }^{104}$

104. See JAMES R. MAXEINER With ARmin Weber AND GyoOHo LeE, Fallures of American Civil Justice in International Perspective (Cambridge Univ. Press 2011) [hereinafter MAXEINER, FAILURES OF AMERICAN Civil Justice]. 
ii. Reasoned explanations. Judges and government officials are required to give reasoned explanations for their findings of fact, conclusions of law and application of law to facts. They must deal in a prescribed form with all possible relevant laws and party assertions. Reasoned opinions are said to help make up for shortcomings of statutes. They enhance the quality of legal decisions. They provide foundations for review of decisions made. Just the knowledge that such a review is possible impels decisionmakers to self-control. It requires them to base their decisions, or at least the justifications for their decisions, on approved reasons (e.g., the statutory requirements) and not on unapproved ones (e.g., bias and prejudice). ${ }^{105}$

\section{COMMON LAw PROCEDURE IS A Problem}

Scalia and Garner courageously confront common law tradition. There is to be no more judicial law making; only legislatures are to make law. Yet Scalia and Garner are haunted by common law procedure and a heritage of neglect of legislation. Their textualism is for litigation and not for life. It speaks to judges and to litigating parties and not to people. Its idea of a statute has more in common with the old writs of common law special pleading than it does with modern codes. Its idea of the role of the judge is that of an oracle who speaks law, not that of a workman who applies law. They fear a text that might give way to considerations of justice or policy, for then it would endanger the rule of law and separation of powers.

Scalia and Garner are clear that their book is a how-to book for judges, ${ }^{106}$ especially appellate judges, who want to interpret law.

105. Id. at 202-03, 228-29.

106. If this were not clear enough from the book itself, Scalia says exactly this in talking about the book. Interview with PBS NewsHour, broadcast August 9, 2012. 
They write "our basic presumption: legislators enact; judges interpret." 107

They do not address how legislators should enact laws. They almost overlook that courts of first instance apply law. ${ }^{108}$ They begin their book: "You be the judge - the appellate judge-for a moment." 109 Yet both writing and applying law are integral to a well-functioning reading of the law.

The poor quality of American legislation is well known. ${ }^{110}$ Although Scalia and Garner do not directly address it in Reading Law, Scalia has stressed the importance of good laws: garbage in, garbage out. 111 He has berated Congress for "Fuzzy, leave-thedetails-to-be-sorted-out-by-the-courts legislation." 112 The United States has laws that we call codes, but they do not integrate laws the way true codes do. ${ }^{113}$ We use indefinite concepts and general clauses, and some are designed that way and do work, but many do

107. SCALIA \& GARNER, READING LAW, supra note 1, at xxx (citations omitted).

108. James Wilson wrote "every prudent and cautious judge ... will remember, that his duty and his business is not to make the law, but to interpret and apply it." [Emphasis added.] Part 2, Chapter V, Of the Constituent Parts of Courts-Of the Judges, in LECTURES ON LAW DELIVERED IN THE COLLEGE OF PHILADELPHIA, IN THE Years ONE ThOUSAND SEVEN HundREd AND Ninety, AND ONE THOUSAND SEVEN HUNDRED AND NINETY ONE, posthumously published in 2 THE WORKS OF THE HONOURABLE JAMES WILSON, 299, 303 (Bird Wilson, 1804); 2 THE WORKS OF JAMES WILSON 500, 502 (Robert Green McCloskey ed., 1967); 2 COLLECTED WORKS OF JAMES WILSON, 950, 953 (Kermit L. Hall \& Mark David Hall eds., 2007).

109. SCALIA \& GARNER, READING LAW, supra note 1 , at 1.

110. See, e.g., ORgANISATION FOR ECONOMIC CO-OPERATION AND DEVEloPMENT, REgULATORY REFORM IN THE UNITED STATES 48 (OECD, 1999) ("At the heart of the most severe regulatory problems in the United States is the [poor] quality of primary legislation."); Mary Ann Glendon, Comment, in SCALIA, A MATTER OF INTERPRETATION, supra note 11, at 95 (our skills with legislation are "primitive.").

111. In a television interview he said: "But in this job, it's garbage in, garbage out. If it's a foolish law, you are bound by oath to produce a foolish result, because it's not your job to decide what is foolish and what isn't. It's the job of the people across the street." C-Span Interview at 1:49:34 (Oct. 8, 2009), http://www.c-spanvideo.org/program/7716-1 (last visited 04/26/13).

112. Sykes v. United States, 131 US 2267, 2288 (2011) (Scalia, J., dissenting).

113. Maxeiner, Costs of No Codes, supra note 9, at 364-65. 
not. ${ }^{114}$ We have discretion, but our granting and controlling of discretion is flawed at best. ${ }^{115}$

If our skills with statutes are poor, our common law procedures may be worse in how they try to apply statutes.

No one knows the law and no one has responsibility for applying it. We share the task of applying law among parties, judges and jurors. In the old common law system of special pleading, the plaintiff chose the form of action, and the parties together, through pleading, identified the point in issue. If an issue of law, the judge interpreted the writ, the statute, or the precedent. No trial was necessary; the legal point decided the case. If an issue of fact, jurors determined the decisive fact that fell under the point of issue. Of course, the law was too complicated for special pleading to work and the United States abandoned it-over Supreme Court objection-in the $19^{\text {th }}$ century. The outward division of responsibilities, however, remains the same: the selection of law is for the parties, the interpretation of law is for the judges, and the findings of fact are for jurors. But the rational application of law is more myth than reality. Either judges take facts as given and decide motions for summary judgment, or they hand the case over to jurors, give them quick, unfathomable instructions on applying law, and pray that jurors do a good job. Of course, this procedure-besides expense-is so unpredictable that it is the rare case that ever ends up being decided by a jury. ${ }^{116}$

Only exceptionally do courts give reasoned explanations for decisions. Jurors are not jurists and they are not thought capable of explaining their decisions. At best - and rarely - they may provide special verdicts or answer special interrogatories. More commonly,

114. See, e.g., James R. Maxeiner, Standard Terms Contracting in the Global Electronic Age: European Alternatives, 28 YALE J. INT'L L. 109 (2003).

115. See KENNETH CULP DAVIS, DisCretIONARY JUSTICE: A PRELIMINARY INQUIRY (LSU Press 1969); MORTIMER K. KADISH \& SANFORD H. KADISH, Discretion to DisObey: A STUdy OF LAWFul DePARTURES From Legal RuLES (Stanford Univ. Press 1973).

116. See MAXEINER, Failures of AMERICAN Civil JustiCE, supra note 104; James R. Maxeiner, Thinking Like a Lawyer Abroad, supra note 24. 
they provide unreasoned general verdicts. Americans know that there is better way. When judges decide alone without jurors they are required to explain their decisions. But bench trials and a judge's reasoning are even rarer in many jurisdictions than are jury trials and verdicts. ${ }^{117}$

How is an appellate court supposed to review such decisions? By American appellate procedure, judges must accept the (unstated) findings of fact of jurors. So if they find the outcome deficient, i.e., unjust or contrary to good public policy, they cannot go back - as their civil law counterparts - and reexamine how law and facts fit together. They are stuck with jiggering, with "interpreting", the law. No wonder they produce decisions that Scalia and Garner find awful. ${ }^{118}$

\section{CONCLUSION}

It is a remarkable event that a sitting justice has called the common law out in no uncertain terms. With textualism, Justice Scalia and Mr. Garner have restored the playing field to its 1830 condition. But pure textualism will not bring us into the present.

Pure textualism takes us back, not to the America of 1789 , but to Blackstone of 1770 and a "law without equity." America's number one originalist forgotten the preamble of the Constitution? "We the people of the United States, in order to form a more perfect union, establish justice, insure domestic tranquility, provide for the common defense, promote the general welfare, and secure the blessings of liberty to ourselves and our posterity, to ordain and establish this Constitution for the United States of America."120

117. $I d$.

118. Id.

119. SCALIA \& GARNER, READING LAW, supra note 1 , at v [unnumbered introductory page].

120. U.S. Const. pmbl.; Scalia and Garner are not alone. According to America's number one proponent of rules, "rule-based and precedent based decision making often require legal decision-makers to do something other than 
We deserve law that honors justice and policy as well as order.

We deserve modern legal methods, not $18^{\text {th }}$ century methods of England or Prussia, but those of the modern civil law. The United States desperately needs modern legal methods for the Age of Statutes. Those methods will encompass not only reading law, but writing law, applying law and teaching law. Justice Story was a master of all four. It will be a great event when the American legal system-perhaps led by Justice Scalia_can do all four well.

the right thing . . . ." FrederiCK SCHAUER, ThINKING LIKE A LAWYER: A New INTRODUCTION TO LEGAL REASONING 212 (Harvard Univ. Press 2009); see also Maxeiner, Thinking Like a Lawyer Abroad, supra note 24. 